\title{
WORD ORDER VARIATION IN PLAUTUS ${ }^{1}$
}

Unlike some other language phenomena, word order is an unavoidable feature of an utterance. It can be observed in any language as it is always necessary to arrange words (provided the language in question discerns such meaningful entities) in some linear order. It is, however, much more difficult to explain it, since its function cannot be fully established in advance. Even with fairly numerous indications of its role, it would be quite bold to attempt a comprehensive analysis of word order phenomena even in Plautus, let alone in Latin as a whole.

A truly pragmatic approach cannot be based on a dichotomy of 'common'2 vs. 'exceptional', since the result would be limited to a set of more or less stringent rules and exceptions. A compromise between syntactic and pragmatic views of word order was partly reached by Daneš (1974).

In keeping with accepted practice, this paper describes the positions of sentence constituents by means of the "schemata Greenbergiana" (Greenberg 1966). Since their appearance, they have met with no less criticism than praise, but they appear convenient and concise enough. One of their main advantages is that they avoid partial description in terms of 'fronting' or 'tailing', which are applicable when discussing exceptions to rules, but are rather out of place when overall patterns are to be determined.

In a language with the so-called free word order, principles of familiarity can be expected to play a significant role in the arrangement of constituents. It is thus tempting to assume that this is the main principle in the classical languages as well. Indeed, attempts have been made ${ }^{3}$ to show that the Functional Sentence Perspective plays a predominant role in Latin (at least Colloquial Latin) word order. This has proved not to be entirely true: "rules" are scarce, and while tendencies can be established in most cases, their universal application is contestable and can seldom be confirmed statistically. The Topic-Comment and Given-New structures of the sentence certainly are a major factor in Latin word order, but neither the only nor the main one.

The fact that the language of Plautus' comedies, although highly stylised in itself, nevertheless reflects the everyday language of Rome, could account for the difficulties presented by the arrangement of words in his works. In colloquial language, the

\footnotetext{
${ }^{1}$ This paper is based on a text presented at the IXth International Colloquium on Latin Linguistics (Madrid, 13-19 April 1997). I am indebted to Ms. Nada Grošelj for her most useful comments and corrections.

2 Or, as is nowadays commonly put in computing language: 'default setting'.

${ }^{3}$ The best known of them is Panhuis (1982).
} 
pragmatic situation and linguistic context play a much greater role than in literary language (i.e. the language of written texts). Moreover, it is important to ensure that the listener perceives what we want to say. To quote from George Kennedy's book about the heritage of ancient rhetoric: " $\mathrm{A}$ speaker has greater need to repeat his main points than does a writer. The audience has little opportunity at any moment to look back at what the orator said ten or twenty minutes before; it has little opportunity to consider the structure as a whole." The same goes, mutatis mutandis, for everyday language. From the viewpoint of the speaker, it is not essential to place the given information before new, as the known information is in most cases obvious enough. Still, the topic has to be repeated in a more or less explicit form to, somehow, ensure the clarity of the message.

Spoken language thus seems to display two contrary tendencies at work:

- a tendency to rely heavily on the pragmatic situation and linguistic context;

- a certain need to repeat from time to time what one is talking about.

\section{Right-Dislocated Topics}

Right-dislocations can be viewed as an interesting hybrid of these two contrary tendencies. The dislocated sentence constituent (in some cases one would even be inclined to say 'topic') is placed at the end of the sentence, though it does not belong to the sphere of 'new' information. It would tend to be translated by a pronoun or not translated at all (omitted). The term 'right-dislocation' itself can only be understood in the sense that something is placed to the right which should rightfully be placed to the left. Obviously, such arrangement of sentence constituents is unexpected and may be viewed as a deviation from the normal word order. Many examples of right-dislocated topics could be found in spite of the fact that the word order in Latin is far from being rigid. ${ }^{5}$

In many cases where the topic is dislocated: "The final constituent is co-denotational with an entity, typically a pronoun or a clitic, in the preceding predication." 6 In Hofmann, ${ }^{7}$ a constituent in this position is described from the opposite viewpoint as 'vorausgeschicktes Pronominalsubjekt/-objekt'.

This first group is represented by the following examples:
(1) Cist. 470f:
Dabo

ius iurandum. || At ego nunc ab illo mihi caveo iure iurando tuo. ${ }^{8}$

\footnotetext{
${ }^{4}$ Kennedy (1980)

5 According to Givón (1983), right-dislocation is common in languages where the word order is rigid.

6 Siewierska (1988), 70.

${ }^{7}$ Hofmann (1936), 120: "Derselbe Typus des vorausgeschickten Pronominalsubjekts bzw. -objekts mit nachträglicher Erlšuterung findet sich bei den altlat. Szenikern."

8 "I'll give my solemn oath." II "But I'm on my guard against that solemn oath of yours." All translated passages are quoted from Paul Nixon's translations in the Loeb Classical Library edition.
} 
(2) Aul. 610f: Edepol ne illic pulchram praedam agat, si quis illam invenerit, aulam onustam auri. ${ }^{9}$

(3) Rud. 471f: sed autem, quid si hanc hinc abstulerit quispiam, sacram urnam Veneris? ${ }^{10}$

(4) As. 74ff: Nam me hodie oravit Argyrippus filius, ut sibi amanti facerem argenti copiam; eid ego percupio, obsequi gnato meo. ${ }^{11}$

It may be noted that the topic in such sentences does not coincide with the sentence subject. On the other hand, other examples can be quoted where the topic is likewise moved into final position, but there is no "pronoun in the preceding predication". While the topic undergoes movement similar to right-dislocation, the syntactic structure of the basic sentence thus remains unchanged. In some of these examples, the topic is in fact represented by the sentence subject:

(5) Mil. 209f: ecce autem aedificat; columnam mento suffigit suo. apage, non placet mihi illaec aedificatio. ${ }^{12}$

One would almost be tempted to place a comma before illaec aedificatio and translate it separately.
Am. 799ff:
adveniensque ilico

me salutavisti, et ego te, et osculum tetuli tibi.

|| Iam illud non placet principium de osculo. /... /

I| Cena adposita est; cenavisti mecum, ego accubui simul. || In eodem lecto? || In eodem. || Ei, non placet convivium. ${ }^{13}$

(7) Rud. 378ff: Cavistis ergo tu atque erus ne abiret, cum scibatis?

|| Quid faceret? || Si amabat, rogas, quid faceret? Adservaret

dies noctesque, in custodia esset semper. Verum ecastor ut multi fecit ita probe curavit Plesidippus. ${ }^{14}$

But similar arrangement also occurs in cases where the topic is a constituent other than the subject.

9 "Oh, my God, what a beautiful haul he would get, if anyone should find it - a pot just crammed with gold!"

10 "Hold on, though, what if someone carried it off - the sacred pitcher of Venus?"

11 "Well now, this very day my boy Argyrippus begged me to supply him with some money, saying he was in love. And $I$ heartily desire to oblige the dear lad."

12 "He is building - supporting his chin with a pillar. None of that! I don't fancy that sort of building."

13 "And the moment you arrived you greeted me, and I you, and I gave you a kiss. II Now I don't like that, that beginning with a kiss. /.../ | | Dinner was served: we dined together: I took my place on the couch, too. || The same couch? || Surely. || Oho! This banqueting looks bad!"

14 "So you and your master took care that he shouldn't get away, knowing that? || What could he have done? 11 Done, you say? If he loved her? He should have kept watch day and night. He should have been on guard always. The fine care Plesidippus took of her quite matches his affection, yes, indeed." 
(8) Truc. 136ff: Nimis otiosum te arbitror hominem esse. || Qui arbitrare?

II Quia tuo vestimento et cibo alienis rebus curas.

|| Vos mihi dedistis otium. ${ }^{15}$

(9) Most. 912ff: Di immortales, mercimoni lepidi. si hercle nunc ferat sex talenta magna argenti pro istis praesentaria, numquam accipiam. /.../

Bene res nostra conlocata est istoc mercimonio. ${ }^{16}$

Examples 10-12 represent corresponding passages from Bacchides and Menander's $\Delta i \varsigma \dot{\varepsilon} \xi \alpha \tau \alpha \tau \tilde{\omega} \nu$, and a sentence with a similar content from Terence's Hecyra.

(10) Bacch. 497f: Mnesiloche, cura ei, concastiga hominem probe, qui dedecorat te, me amicosque flagitiis suis.

(11) The corresponding fragment from Menander's $\Delta i \varsigma$ ह่ $\xi \alpha \pi \alpha \tau \tilde{\omega} \nu$ 15ff: ${ }^{17}$

$$
\alpha u ̛ \tau \tilde{\omega}, \Sigma \omega ́ \sigma \tau \rho \alpha \tau \varepsilon \text {, }
$$

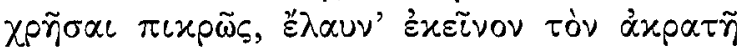

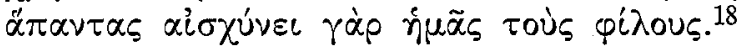

In the Greek passage, there is no trace of a right-dislocated topic (flagitiis suis in the corresponding Latin verse); it has obviously been added by the Latin author. A sentence expressing the same idea can be found in Terence's Hecyra:

(12) Hec. 210: quae me et te et familiam dedecoras, filio luctum paras.

Since Terence's style is usually closer to his Greek models (although the Greek original of this play is only hypothetical), it could be speculated that right-dislocated topics are more common in Plautus than in Terence.

In the next example, the topic has been re-focussed:

(13) Curc. 319f: Iam edes aliquid. II Nolo hercle aliquid. Certum quam aliquid mavolo. ${ }^{19}$

15 "I judge that you're quite a gentleman of leisure. || Why do you judge that? || Because you mind other folks' affairs without charging them or your clothes and keep. | | You girls have given me the leisure."

16 "Ye immortal gods! What a lovely bargain! By Jove, if he should come and offer me a cool eighteen hundred pounds for it, cash down, I would never take it. /... / Our money is well invested in such a bargain."

17 The passage is quoted from: T. Maccius Plautus, Bacchides, nota introduttiva e testo critico di Cesare Ques-

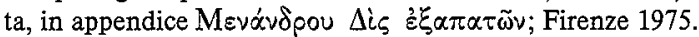

18 "Mnesilochus, take charge of him! Go, rate him well - for degrading you, and me and his other friends with his enormities."

19 "You shall have something to eat at once. || Oh Lord! It is not 'something' I want; I prefer a definite thing to just 'something'." 


\section{Topic Fronting}

In most cases, what is often called the 'topic' in P1-position could be argued to represent a 'contrastive focus'. (In Greek, the sentence element which is usually ${ }^{20}$ referred to as a contrastive focus is additionally marked by the $\mu \varepsilon^{\prime} \nu-\delta \varepsilon^{\prime}$ particle pair.) In terms of the topic-comment structure, one might be inclined to treat such elements as topics for the following reasons:

- If such elements were considered as contrastive foci, sentences such as (14) Calpurnio Numidia, Scipioni Italia obvenit (Sall., Bellum Iug. 27.4) would have more than one focus, as the first focus would be contrastive and the second non-contrastive.

- Both elements of the pair are given or known (from the previous context).

- Finally, such contrastive elements are paraphrased with a different type of cleft sentence in English than non-contrastive ones. The former could be translated as: "As for Calpurnius, he was given Numidia," whereas the normal focus could be expressed as: "It was Numidia that was given to Calpurnius."

Several well-known examples could be given to illustrate what is meant here by the term 'contrastive focus' or 'contrastive topic'. In such sentences, one of several possible topics is always chosen:

(15) Truc. 188: Estne nunc intus Phronesium? || Utut aliis, tibi quidem intus. ${ }^{21}$

(16) Ps. 78f: Nilne adiuvare me audes? || Quid faciam tibi?

|| Eheu. || Eheu? id quidem hercle ne parsis. dabo. ${ }^{22}$

(17) Most. 208ff: Inscita ecastor tu quidem es. || Quapropter? || Quae istuc cures, ut te ille amet. /.../

|| Scapha, id tu mihi ne suadeas, ut illum minoris pendam. ${ }^{23}$

In the case of a contrastive focus, the contrasting clauses often display parallel arrangement of constituents:

(18) Poen. 1089f: Potin tu fieri subdolus? || Inimico possum, amico insipientia est.

|| Inimicus hercle est huius. || Male faxim lubens. ${ }^{24}$

(19) Mer. 627f: De istac re argutus es, ut par pari respondeas, ad mandata claudus caecus mutus mancus debilis. 25

20 E.g. Pinkster (1983), 264.

21 "Is Phronesium in now? || To you she is, whatever she is to others."

22 "Are you not willing to help me at all? || What am I to do for you? || Ah me! || 'Ah me'? Gad, spare no 'Ah me's'. I'll supply them."

23 "My goodness! Such a little stupid! || Why? || To care about his loving you. /../ || And don't try to make me think any less of him, Scapha."

24 "Can you be wily, sir? || With an enemy, yes; with a friend it's foolish. $\mid 1$ He's an enemy of master's all right. | I will enjoy damaging him."

25 "You're ready enough to repartee, but in carrying out commissions you're a lame, blind, mute, maimed remnant of a man!" 
If the topic is contrasted in an interrogative sentence, it may even drive the question particle out of the P1-position. As expected, the question particles normally occupy the initial position in the clause, but this is easily overruled by pragmatic factors. Thus the initial position is occupied by the sentence topic or focus even if this involves displacing the question particle or the sentence connectors. These occur in the second position and - very appropriately - serve as a boundary between the topicalised element and the rest of the sentence:

(20) Cist. 655ff: sed eccam eram video. sed quid hoc est, haec quod cistella hic iacet cum crepundiis? nec quemquam conspicor alium in via. /.../

|| Quid agis, Lampadio? || Haec cistella numnam a nobis a domo est? nam hic ab ostio iacentem sustuli. ${ }^{26}$

Similar treatment of the sentence topic can be observed in two more sentence types:

a) examples 21 and 22 where the topic change is marked by sed; the topic precedes the negative particle and the interrogative pronoun respectively:

(21) As. 394f: Ubi est? \| Ad tonsorem ire dixit.

|| Conveni. Sed post non redit? || Non edepol. ${ }^{27}$

(22) Mil. 1019f: Enim cognovi nunc, fecisti modo mi ex proclivo planum. Sed hic numquis adest? ${ }^{28}$

b) in some rather formal interrogative sentences whose topic has been previously mentioned more than once. In such cases the topic precedes the question particle (or, as in 23 , the word to which the latter is appended) or the interrogative pronoun (as in 24):

(23) Ps. 1067ff: Quid est igitur boni?

I) Minae viginti salvae et sanae sunt tibi, hodie quas aps te est instipulatus Pseudolus.

|| Velim quidem hercle. || Roga me viginti minas, si $/ . . . /$

II Nullum periclumst, quod sciam, stipularier, ut concepisti verba. Viginti minas

dabin?|| Dabuntur. ${ }^{29}$

26 "Aha, though! there's the mistress. But what does this mean? A little casket lying here - with toys? No one else in the street, apparently. /.../ | | What are you doing, Lampadio? | This casket - can it have come from our house? It was lying here by the door when I picked it up."

27 "Where is he? || Said he was going to the barber's. | I I met him. But has he not been back since? || Lord, no!"

28 "Ah, now I know, now you have made the rough places plain! But is anyone about here?"

29 "What's the good news, then? I I It's safe and sound, your eighty pounds that Pseudolus engaged to get from you to-day. | Egad! I only wish it were. I| Come, make formal demand that I pay you eighty pounds, if he gets hold $/ \ldots /$. I There's no risk, as far as I see, in taking you up on the terms you've set. You will pay me eighty pounds? || I will." 
(24) Most. 637ff:

tuos emit. || Aedis? || Aedis. || Euge, Philolaches

patrissat: iam homo in mercatura vortitur.

ain tu, aedis? || Aedis inquam. sed scin quoius modi? /.../

I Bene hercle factum. quid? eas quanti destinat?

I| Talentis magnis totidem, quot ego et tu sumus. ${ }^{30}$

A different explanation is required when the element occurring in the P1-position functions as a comment. The context and - in some cases - additional grammatical markers (such as disjunction-separated NP's) render such sentences highly emphatic:

(25) Mer. 658f: hoc mihi certissumumst,

eo domum, patrem atque matrem ut meos salutem, postea

clam patrem patria hac effugiam aut aliquid capiam consili. ${ }^{31}$

(26) Truc. 166ff: qui antehac amator summus habitu's, nunc ad amicam venis querimoniam deferre. I| Vestra hercle factum iniuria, quae properavistis olim: Rapere otiose oportuit, diu ut essem incolumis vobis. ${ }^{32}$

(27) Poen. 1264: Vix hoc videmur credere. || Magis ${ }^{33}$ qui credatis, dicam.

(28) Mil. 1420: Ergo des minam auri nobis. || Quamobrem? || Salvis testibus ut ted hodie amittamus, Venerium nepotulum. ${ }^{34}$

\section{Verb-Initial Sentences}

Latin verb-initial sentences are often treated either as exceptions (as sentences with zero-topics, or at least zero-expressed topics) or as structures with right-dislocated topics (in Givón's terms). Yet it could be argued that the verb can likewise participate in the topic-comment (or 'given-new') structure of the sentence (the familiarity hierarchy). One can easily imagine a situation where the action is given, while the information to be provided refers to the agent or patient. In this case, the verb is the bearer of the known information. Therefore it plays the role of the sentence topic, filling the P1-position in the sentence.

30 "Your son has bought a house. || A house? || A house. || Ah, that lad's capital! A chip off the old block! Quite a business man already! A house, you say? || Yes, sir, a house. D'ye know what kind of a house, though? /... | | Bless my soul, that's fine. Er - how much did it cost him? || Three hundred pounds, sir, times the sum of you and me."

31 "This is my fixed intention. I shall go home to pay my respects to my father and mother, and then without my father's knowledge I shall flee this country or settle upon some plan."

32 "You, the lover that once stood supreme, now come and bring your sweetheart - wails. I| Good Lord! That's due to your bad tactics; you girls were in too much of a rush. More leisurely marauding was the thing, so that I should last you longer."

33 "It all seems so hard for us to believe! | I You'll believe it the easier for this."

34 "Well then, give us twenty pounds. | | What for? | | For letting you get away with your witnesses intact, you dear little grandson of Venus!" 
This approach to the verb solves some problems which would remain puzzling if it was excluded from the topic-comment structure. Particularly in an SVO language, it is tempting to view the verb as an orientation point: the constituents placed to its left belong to Topic, whereas those to its right belong to Comment. If, however, the basic order in a language is SOV (as seems to be the case in Latin), this point of view brings more difficulties, since the immediate constituents need to be distinguished from the rest of the sentence. The communicative role of the verb is thus not as obvious as it is in an SVO language.

A special problem is presented by the pronominalised constituents (i.e. those expressed as pronouns), which are best treated separately. Plautine texts reveal a well-known tendency for pronouns to cluster in groups, suggesting that the placing of, for example, pronominal subjects is greatly influenced by non-syntactic, mainly prosodic factors. ${ }^{35}$ Thus the examples adduced should be ones where the topic and comment are not expressed merely by pronouns.

The word order in verb-initial sentences could be explained by the fact that the Latin subject can be expressed by the verb form itself, not necessarily by a pronoun (it is not obligatory). This is called 'zero-pronominalization'36 by De Jong.

What can be considered as the most reasonable explanation of verbs in the P1position is given by Pinkster $(1988,267) .^{37}$

The verb in this case is assumed to be the sentence topic, thus legitimately occupying the initial position.

A topical verb is likely to occur in texts where the main topic remains the same and only the sub-topics change. The sub-topic tends to be placed towards the beginning of the clause even if it does not coincide with the grammatical subject. A good general example of such arrangement is the following extract (in this case, however, the sub-topics are in fact non-verbal and mostly represented by clause subjects):

(29) Trin. 520ff (a vivid description of a field on which a curse has been cast; the change of sub-topics is marked by a change in letter size):

Per deos atque homines dico, ne tu illunc agrum

tuom siris umquam fieri neque gnati tui.

ei rei argumenta dicam. /.../

Primum omnium olim terra quom proscinditur,

in quinto quoque sulco moriuntur boves.

/...

Tum vinum prius quam coctumst pendet putidum.

$\mid \ldots /$

35 This is one of the possible criticisms of Dirk Panhuis' research on the Functional Sentence Perspective in Latin (Panhuis 1982): the author often attempts to explain the placing of a pronominal constituent exclusively by means of the topic-comment structure.

36 Cf. De Jong (1985), 527.

${ }^{37}$ About Caes. BG. I.9.1 (Relinquebatur una per Sequanos via): "Diese (= die Anfangsstellung) könnte auch damit erklärt werden, daß relinquebatur als Topic oder als kontrastiver Fokus (d.h. als Kontrast zu dem implizierten 'der eine Weg fiel aus') fungiert." 
post id, frumenti quom alibi messis maximast, tribus tantis illi minus redit, quam opseveris.

/.../

Neque umquam quisqamst, quoius ille ager fuit, quin pessume ei res vorterit: quoium fuit, alii exulatum abierunt, alii emortui, alii se suspendere. em nunc hic quoius est, ut ad incitas redactust.

/.../ nam fulguritae sunt alternae arbores, sues moriuntur angina acerrume; oves scabrae sunt, tam glabrae, em, quam haec est manus. tum autem Surorum, genus quod paientissumumst hominum, nemo extat qui ibi sex menses vixerit. ${ }^{38}$

The narration continues, but this may be enough to illustrate our point.

When the sub-topics are verbal, the resulting verb-initial sentences typically form part of a longer descriptive text. This time it is Pliny the Elder who provides us with an example:

(30) Pliny, Hist. Nat. VII.20-22:

Velocissimum omnium animalium, non solum marinorum, est delphinus /.../

Vagantur fere coniugia;

pariunt catulos decimo mense aestivo tempore, interim et binos.

nutriunt uberibus, sicut ballaena, atque etiam gestant fetus infantia infirmos;

/.../ adolescunt celeriter, $X$ annis putantur ad summam magnitudinem pervenire.

Vivunt et tricenis, quod cognitum praecisa cauda in experimentum. abduntur tricenis diebus circa canis ortum

occultanturque incognito modo. ${ }^{39}$

38 "By all that's holy, sir, never let that farm come into our hands or your son's. And l'll tell you my reasons for saying so. /.../ Well, to begin with, sir, whenever that land's first ploughed, why, in every fifth furrow the oxen drop dead. /.../ And then the grapes, sir - they hang there and rot before they're ripe./.../ Moreover, sir, when every one else has a whopping harvest, that farm yields three times less than you sow. /.../ Why, sir, never a soul owned that farm without things turning perfectly awful for him: some of its owners went into exile, others died off, others - hanged themselves. And just look at its present owner - swept right off the board! /.../ Yes sir, every other tree is struck by lightning; the swine all sicken and die from awful attacks of - quinsy; the sheep get mangy, they've no more wool on'em than - look! - this hand here. And besides that, the slaves Syrians, the most enduring breed there is - not one of 'em that stayed there six months is alive to-day."

39 "The swiftest of all animals, not only of those of the sea, is the dolphin /.../ They usually roam about in couples, husband and wife; they bear cubs after nine months, in the summer season, occasionally even twins. They suckle their young, as do whales, and even carry them about while weak from infancy. /.../They grow up quickly, and are believed to reach their full size in 10 years. They live as much as 30 years, as has been ascertained by amputating the tail of a specimen for an experiment. They are in retirement for 30 days about the rising of the dog-star and hide themselves in an unknown manner." 
Similar stretches of narrative can be found in Plautus. In a passage from Curculio, a parasite reports on his journey to Caria, where he was sent by his "patron".

(31) Curc. 329-340:

postquam tuo iussu profectus sum, perveni in Cariam.

video tuom sodalem, argenti rogo uti faciat copiam.

scires velle gratiam tuam, noluit frustrarier,

ut decet velle hominem amicum amico atque opitularier.

respondit mihi paucis verbis, atque adeo fideliter,

quod tibi est item sibi esse, magnam argenti inopiam.

$\mid \ldots /$

postquam mihi responsum est, abeo ab illo maestus ad forum

med illo frustra advenisse. forte aspicio militem.

adgredior hominem, saluto adveniens. "salve" inquit mihi,

prendit dexteram, seducit, rogat quid veniam Cariam.

dico me illo advenisse animi causa. ${ }^{40}$

Most of the above verbs contain information about familiar steps normally taken on such a journey. They are to some extent predictable and therefore suited to the topic role.

There are of course many passages in Plautus where the initial position of the verb requires a different explanation, as for instance:

(32) Trin. 598ff: Edepol re gesta pessume gestam probe,

si quidem ager nobis salvos est; etsi admodum

in ambiguo est etiam nunc quid ea re fuat.

sed si alienatur, actumst de collo meo,

gestandust peregre clupeus, galea, sarcina:

effugiet ex urbe, ubi erunt factae nuptiae,

ibit istac, aliquo, in maximam malam crucem,

latrocinatum, aut in Asiam aut in Ciliciam. ${ }^{41}$

40 "After setting out according to your orders, I arrived in Caria. I saw your chum and asked him to supply you with the cash. You should not doubt his good will, he disliked to disappoint you, he wanted to do the proper thing as between friends, and help you. His answer was brief and perfectly sincere - that he was in the same box as you, very short of funds. /.../ After getting his answer, off I go to the forum, feeling glum at having come there all for nothing. It so happens I see a military man. Up I step and say good day to him. 'Good day to you,' says he, and seizes my hand, takes me aside, and asks me what I have come to Caria for. 'A pleasure trip,' says I."

41 "Ah, there's a happy ending to a bad beginning, that is, if the farm's saved for us! Yet that's something there's considerable uncertainty about still. If it is given away, though, I'll get things in the neck, sure enough - as his shield, helm and pack bearer in foreign service. He'll flee the city once the wedding's over, and be off yonder somewhere bound for particular blazes, soldiering in Asia or Cilicia." 
Since this passage portrays a slave lamenting his fate if the field should be given away, the word order can be explained as emphatic. A similar case are exclamatory sentences with initial auxiliary verbs:

(33) Bacch. 120f: An deus est ullus Suavisaviatio?

| I An non putasti esse umquam? o Lyde, es barbarus; ${ }^{42}$

(34) Ps. 74: Est misere scriptum, Pseudole. $\| O$, miserrime. ${ }^{43}$

\section{SVO in Some Utterance Types?}

In Plautus, the verb undeniably tends to come last in a given sequence of constituents. However, some exceptions do occur.

As one of the main criteria, the relative length of constituents should be taken into consideration: if the object is - vaguely speaking - long (meaning something like 'consists of more than three words'), it follows the verb (the so-called End Weight principle $)^{44}$. This is particularly common in sentences where several objects are being enumerated:

(35) Ps. 810ff: Non ego item cenam condio ut alii coqui,

qui mihi condita prata in herbis proferunt, /.../

indunt coriandrum, feniculum, alium, atrum holus,

apponunt rumicem, brassicam, betam, blitum $/ . . . / 45$

(36) Cas. 493: Emito sepiolas, lopadas, lolingulacas, hordeias. ${ }^{46}$

Enumeration of this kind is often enlivened through verb repetition:

(37) Cap. 159ff: Non pol mirandum est fugitare hanc provinciam.

multis et multigeneribus opus est tibi

militibus: primumdum opus est Pistorensibus:

eorum sunt aliquot genera Pistorensium: (right-dislocated Topic)

opus Paniceis est, opus Placentinis quoque;

opus Turdetanis, opus Ficedulensibus.

iam maritumi omnes milites opus sunt tibi. ${ }^{47}$

42 "You mean to say that there is a god Kissykissysweet kins? | | You mean to say you didn't ever suppose there was? Oh, Lydus, you are a barbarian!"

43 "She writes so woefully, Pseudolus! || Oh, so damned woefully!"

${ }^{44}$ I am grateful to Ms. Nada Grošelj for having pointed out this term.

45 "I am a man who seasons a dinner differently than other cooks, who season me whole plantations and put'em on the platters /.../ They serve them sorrel, cabbage, beets, spinach, flavoured with coriander, fennel, garlic, parsley /.../."

46 "Get some little sepias, and limpets, and little cuttles, and grainings."

47 "Bless my soul! no wonder they fight shy of it (= the office). You need many recruits, of many sorts, too: why, in the first place you need Pad-u-ans; and there are several kinds of Paduans: you need the support of Bologna, and you need Frankfurters too; you need Leghorners and you need Pisans, and furthermore you need every fighter in fin land." 
(38) Truc. 902ff:

Puero opust cibo, opus est matri autem, opus est quae puerum lavit, opus nutrici, lact ut habeat, /.../,

/.../ opust ligno, opust carbonibus,

fasciis opus est, pulvinis, cunis, incunabulis,

oleo opus est, opus est farina, porro opus est totum diem. ${ }^{48}$

(39) Cap. 378ff: nunc ita convenit inter me atque hunc, Tyndare ut te aestumatum in Alidem mittam ad patrem. /.../

/.../

| | Recte convenisse sentio.

Nam pater exspectat aut me aut aliquem nuntium, qui hinc ad se veniat. ${ }^{49}$

\section{A Different Text Type}

There is another factor that might be relevant: the text type. Although word order variation in Plautus rarely appears to be motivated by the text type, it could be suggested that the verb tends to be placed before its complements if the text is a narrative one. In this case we might distinguish between two word order variants: narrative and persuasive. Here is a tentative example from Menaechmi:

(40) Men. 1053ff:

erupui, homines quom ferebant te sublimen quattuor,

Quin modo

apud hasce aedis. tu clamabas deum fidem atque hominum omnium,

quin ego accurro teque eripio vi pugnando ingratiis.

ob eam rem, quia te servavi, me amisisti liberum. ${ }^{50}$

In the following passage, the speaker is presumably trying to sound like a fishing expert. Therefore the narrative type is used.

(41) Rud. 993ff: Quid, tu numquam audisti esse antehac vidulum piscem? || Scelus,

nullus est. || Immo est profecto; ego, qui sum piscator, scio.

verum raro capitur, nullus minus saepe ad terram venit /.../.

48 "The child needs food; the mother needs it too; the woman that bathes him needs it; the nurse has her needs - so as to have milk (she must drink lots and lots of old wine day and night); we need wood, we need coal, we need baby linen and pillows and cradle and cradle bedding; we need oil, we need farina."

49 "Tyndarus, this gentleman and I have just arranged that I send you to Elis to father, under a forfeit. /.../ I And a good arrangement, too, in my opinion. For the old gentleman's expecting either me or some messenger to come to him from here."

50 "Why, sir, I just now rescued you when four men were carrying you off on their shoulders in front of this very house. You were yelling for all heaven and earth to help you, when up I ran and rescued you by good hard fighting, in spite of 'em. And for this, because I'd saved you, you've set me free." 
Quo colore est, hoc colore capiuntur pauxilluli;

sunt alii puniceo corio, magni item; atque atri. ${ }^{51}$

Compare the following passage from Pliny the Elder:

(42) Pliny, Hist. Nat. IX.3.8:

Maximum animal in Indico mari pristis et ballaena est. /.../ apparent et rotae

appelatae e similitudine, quaternis distinctae hae radiis $/ . . . / 52$

\section{Conclusion}

In Plautus, some of the apparent deviations from the canonical Latin word order can be explained with the topic-comment structure. The overall picture shows a clear preponderance of SOV or at least OV ordering, yet in some cases SVO emerges as the almost regular pattern. By way of a conclusion, we may be permitted to raise a question: to what extent should the role of pragmatics be taken into account? In other words: if word order is syntactically determined (i.e. in terms of sentence constituents), should pragmatics be referred to only when the actual usage cannot be explained otherwise? This question is of vital importance to the role of pragmatics in accounting for the arrangement of words.

It is also possible to distinguish between at least two text types with their own 'unmarked' word order, thus avoiding the necessity to postulate one single basic order for every possible utterance. These text types could be broadly characterised as the Narrative and Persuasive types. In Narrative Type, the Functional Sentence Perspective would be the major factor, as text cohesion is less dependent on nonlinguistic means. In Persuasive Type, by contrast, constituents often "break ranks", being sufficiently backed by their shared topic as well as the overall communicative intention.

\section{References}

De Jong (1985): J. R. De Jong, Position of the Latin Subject. In: G. Calboli (ed.), Subordination and Other Topics in Latin, Amsterdam/Philadelphia, pp. 521-540

DANEŠ (1974): F. Daneš, Functional Sentence Perspective and the Organization of the Text. In: F. Daneš (ed.), Papers in Functional Sentence Perspective, Prague: Academic, pp. 106-128

Grvón (1983): T. Givón, Topic Continuity in Discourse: An Introduction. In: T. Givón (ed.), Topic Continuity and Discourse: Quantitative Cross-Language Studies, Amsterdam

GreENBERG (1966): J. H. Greenberg, Some Universals of Grammar with Particular Reference to the Order of Meaningful Elements; Universals of Language II, 72-113

HoFmANN (1936): J. Hofmann, Lateinische Umgangssprache, Heidelberg

KENNEDY (1980): A. Kennedy, Classical Rhetoric and Its Christian and Secular Tradition from Ancient to Modern Times, London

51 "What? You never heard tell of the trunk-fish before? || There's no such thing, scoundrel! || Indeed? Of course there is. I'm a fisherman and I know. They're scarce, I grant you; there's not a fish landed less often. $/ \ldots /$ As for the colour - it's generally little fellows they catch the colour of this one; there are others with red skins - they're big ones like mine. You find black ones, too."

52 "The largest animals in the Indian Ocean are the shark and the whale. /... The creatures called Wheels from their resemblance to a wheel also put in an appearance, these radiating in four spokes." 
Panhuis (1982): D. Panhuis, The Communicative Perspective in the Sentence. A Study of Latin Word Order, Amsterdam

PINKSTER (1988): H. Pinkster, Lateinische Syntax und Semantik, Berlin

SIEWIERSKA (1988): A. Siewierska, Word Order Rules, London-New York-Sydney

Universals of Language II: Greenberg, J. H (ed.), Universals of Language II, Cambridge (Mass.)-London, 1966

\section{Povzetek}

\section{BESEDNOREDNE INAČICE PRI PLAVTU}

Docela pragmatičen pristop $\mathrm{k}$ raziskovanju besednega reda ne more izhajati iz nasprotja 'običajno - posebno', ker bi iz njega dobili samo omejeno število pravil z izjemami, od katerih bi bilo treba vsako razlagati posebej. Bolj sprejemljiv način dela bi bil kompromis med skladenjskim in pragmatičnim načinom dela, kot ga je dosegel Daneš. Za razliko od npr. slovanskih jezikov se je $\mathrm{v}$ raziskavah latinščine izkazalo, da je členitev po aktualnosti samo eden od dejavnikov, ki določajo besedni red.

Jezik Plavtovih komedij je sicer slogovno zelo izdelan, a vendarle odseva vsakdanji jezik mesta Rima, zato preučevanje besednega reda $\mathrm{v}$ njegovih komedijah nikakor ni preprosto. $\mathrm{V}$ govorjenem jeziku namreč opažamo dva nasprotna pojava: udeleženci v pogovoru se na eni strani zanašajo na pragmatično situacijo in jezikovno sobesedilo, a vendarle od časa do časa ponovijo, kar so že povedali.

Kot posledica takega nasprotja lahko nastane t. i. 'zapostavljeno izhodišče', kjer stoji na koncu stavka prvina, ki ne pove ničesar novega, ampak je namenjena navezovanju na že prej poveđano.

V latinščini je moč opaziti tudi težnjo po izpostavljanju izhodišča, ki povzroči, da se prvina, ki se nanjo navezuje ostali del stavka, postavi na prvo mesto, celo pred pođredni veznik ali členice, ki sicer stojijo na začetku stavka.

V pragmatični slovnici lahko nastopijo težave, ko je treba pojasniti primere, $v$ katerih stoji na začetku stavka osebna glagolska oblika. Taki primeri nastopijo, če je osebek izražen s povedkom (v tem se latinščina prav nič ne razlikuje od slovenščine), zlasti, kadar se na skupno izhodišče navezuje več jeder.

Nekatere značilnosti Plavtovega jezika kažejo, da bi bilo moč za latinščino predpostaviti dve osnovni različici besednega reda, namreč pripovedovalno (z osnovnim vzorcem SVO) in prepričevalno (z osnovnim vzorcem SOV). 